\title{
Catabolite repression in the hyperthermophilic bacterium Thermotoga neapolitana is independent of CAMP
}

\author{
Madeline Vargasł and Kenneth M. Noll \\ Author for correspondence: Kenneth M. Noll. Tel: +1 860486 4688. Fax: +1 8604864331. \\ e-mail: noll@uconnvm.uconn.edu
}

Department of Molecular and Cell Biology,

University of Connecticut, Storrs, CT 06269-3125, USA

\begin{abstract}
Thermotoga neapolitana is a hyperthermophilic bacterium whose phylogenetic lineage includes the most primitive of the bacterial heterotrophs. It is not known whether Thermotoga exhibits preferences for growth substrates or regulates the synthesis of degradative enzymes. We have found that $T$. neapolitana exhibits diauxic growth in medium containing $300 \mu \mathrm{M}$ glucose and $1 \mathrm{mM}$ lactose. We measured the activity of $\beta$-galactosidase and $\beta$-glucosidase in extracts prepared from cells grown on defined media and found that cells grown on $0.5 \%$ lactose, galactose or cellobiose contained $\beta$-galactosidase specific activities of 1.19, 1.78 and $1.34 \mathrm{U}$ (mg protein) ${ }^{-1}$, respectively. Cells grown on $0.5 \%$ glucose, maltose, fructose, sucrose, xylose, ribose or starch had no measurable $\beta$-galactosidase activity. $\beta$-Glucosidase activity was found only in cells grown on cellobiose. Cells grown on the combination of $0.5 \%$ lactose or galactose and $0.05 \%$ glucose had no detectable $\beta$-galactosidase activity, whereas up to $0.5 \%$ glucose did not prevent expression of $\beta$-galactosidase or $\beta$ glucosidase activity in cells induced with $0.5 \%$ cellobiose. These activities are catalysed by separate enzymes as determined by resolution of their activities on $6 \%$ native polyacrylamide gels. Therefore, only $\beta$-galactosidase synthesis induced by lactose is subject to catabolite repression. To determine the mechanism of catabolite repression, the levels of CAMP were measured in T. neapolitana cells grown on various defined media using an enzymeimmunoassay. The CAMP levels ranged from 44 to $280 \mathrm{fmol}^{(m g}$ protein) ${ }^{-1}$ irrespective of the carbon source used. By comparison, Escherichia coli grown on lactose contained $5.1 \mathrm{pmol}^{(\mathrm{mg} \text { protein) }}{ }^{-1}$. Like Gram-positive bacteria, $T$. neapolitana displays a cAMP-independent mechanism for catabolite repression and this may represent the more ancient mode of regulation.
\end{abstract}

Keywords: Thermotoga neapolitana, cAMP, catabolite repression, glucose effect, extreme thermophile

\section{INTRODUCTION}

Thermotoga neapolitana is a Gram-negative anaerobic bacterium that has been isolated from submarine hot springs and continental solfataric springs (Belkin et al., 1986; Windberger et al., 1989). It is a hyperthermophile, growing at temperatures up to $90{ }^{\circ} \mathrm{C}$. Because it is the only hyperthermophile able to grow on defined media using a number of polysaccharides and simple sugars as sole carbon sources (Belkin et al., 1986; Jannasch et al.,

†Present address: Department of Biology, College of the Holy Cross, Worcester, MA 01610, USA.
1988), it is uniquely suited to studies of the regulation of carbohydrate catabolism. As determined by $16 \mathrm{~S}$ rRNA sequence comparisons, the genus Thermotoga belongs to the second-deepest bacterial phylogenetic branch and includes the most primitive heterotrophs (Woese, 1987). This early evolutionary divergence makes Thermotoga an excellent benchmark organism for comparative analyses within the bacterial domain as well as between the Archaea, Eukarya and Bacteria.

It is not known whether Thermotoga prioritizes growth substrates or how it regulates the synthesis of degradative enzymes. One of the best studied systems of gene regulation in prokaryotes is the expression of genes 
involved in lactose utilization. In the 1940s, Jacques Monod discovered that the presence of glucose in the growth medium inhibits the synthesis of $\beta$-galactosidase, termed the 'glucose effect' (Monod, 1947) and later catabolite repression (Beckwith, 1987). This phenomenon has been examined most extensively in Escherichia coli and related organisms. The best example involves diauxic growth in media containing glucose and lactose, where glucose is utilized first, followed by a short lag period and growth on lactose. This regulation is, in part, due to a positive regulatory mechanism in which the catabolite repressor protein/cAMP complex binds to a specific site in the promoter region of the lactose operon, increasing its expression (Botsford \& Harman, 1992; Beckwith, 1987; Magasanik \& Neidhardt, 1987). This type of regulation, however, is not universal among prokaryotes. None of the Gram-positive bacteria studied thus far use cAMP in the regulation of $\beta$-galactosidase (Chambliss, 1993). Gram-postive and Gram-negative bacteria belong to different phylogenetic lineages, raising the question of which mode of regulation is evolutionarily more ancient. Examining $\beta$-galactosidase regulation in an early branching bacterium such as $T$. neapolitana allows us to determine whether cAMP-dependent or cAMP-independent regulation appeared first in the bacterial domain.

In this communication, we present the first evidence for catabolite repression in a hyperthermophilic bacterium. We show that $T$. neapolitana is able to regulate $\beta$ galactosidase synthesis and exhibit diauxic growth in media containing glucose and lactose. We found that different sugars affect $\beta$-galactosidase expression differently. Finally, we present data showing that cAMP does not appear to be involved in $\beta$-galactosidase regulation, as found in Gram-positive bacteria. The phylogenetic position of this bacterium suggests that cAMPindependent regulation is the ancestral mode of regulation for induction of $\beta$-galactosidase synthesis.

\section{METHODS}

Culture conditions. T. neapolitana NS-E was cultured in defined TB medium (TB medium without yeast extract, supplemented with a vitamin mixture, $0.5 \%, \mathrm{w} / \mathrm{v}$, cystine and $0.5 \%, \mathrm{w} / \mathrm{v}$, carbohydrate) as described previously by Childers et al. (1992). Briefly, the medium was dispensed into serum or Wheaton media bottles (for larger culture volumes), heated in a steam box and sealed. The atmospheres of the containers were exchanged five times with oxygen-free nitrogen while the medium was still hot. The culture tubes and serum bottles were pressurized to $100 \mathrm{kPa}$ and sterilized by autoclaving. Prior to inoculation, carbohydrates were added to the media from a $20 \%(\mathrm{w} / \mathrm{v})$ filtersterilized anaerobic stock solution. Inocula were $1-2 \%(\mathrm{v} / \mathrm{v})$. The cultures were incubated at $77^{\circ} \mathrm{C}$ for $17 \mathrm{~h}$ (unless otherwise noted). E. coli $\mathrm{K} 12$ was grown on M9 salts (Sambrook et al., 1989) with $0 \cdot 5 \%(\mathrm{w} / \mathrm{v})$ carbohydrate at $37^{\circ} \mathrm{C}$ for $7 \mathrm{~h}$.

Cultures were cooled at room temperature and the cells were harvested by centrifugation and washed twice in $30 \mathrm{ml}$ Thermotoga diluent (Childers et al., 1992) or saline (E. coli). Cell extracts were prepared by lysing $1 \mathrm{ml}$ cells using a Branson sonifier with the output control setting at 2 and the pulse control at $50 \%$ for $1-2 \mathrm{~min}$. Whole cells and cell debris were removed from the extracts by centrifugation at $12000 \mathrm{~g}$.
Enzyme assays. Triplicate $100 \mathrm{ml}$ cultures of $T$. neapolitana grown in $100 \mathrm{ml}$ defined media containing $0.5 \%(\mathrm{w} / \mathrm{v})$ glucose, lactose, cellobiose, sucrose, maltose, fructose, xylose, ribose, galactose, starch or a mixture of $0.5 \%(\mathrm{w} / \mathrm{v})$ lactose and $0.05 \%$ $(\mathrm{w} / \mathrm{v})$ glucose were used to determine the enzyme activities in cell-free extracts. $\beta$-Galactosidase and $\beta$-glucosidase activities were measured using ONPG and 0 -nitrophenyl $\beta$-D-glucopyranoside (Sigma) as substrates essentially as described by Sambrook et al. (1989). The reaction was carried out at $77^{\circ} \mathrm{C}$ for 5-10 min using 8-30 $\mu \mathrm{g}$ cell-free extracts. A reaction mixture without extract was used to measure hydrolysis of the substrate at the elevated temperature. Reaction rates were corrected for this value. Discontinuous measurements of activity (within the linear range of the assay) were made using different volumes of cell extracts to determine the specific activities. One unit was defined as $\mu \mathrm{mol}$ product formed $\mathrm{min}^{-1}$ and the specific activity was calculated as $\mathrm{U}(\mathrm{mg} \text { protein })^{-1}$. The method described by Bradford (1976) was used to measure the protein content of the cell extracts.

Enzyme activity in native polyacrylamide gels. Cell-free extracts prepared from cells grown in defined glucose, lactose or cellobiose media were resolved using $6 \%(\mathrm{w} / \mathrm{v})$ native PAGE as described elsewhere (Sambrook et al., 1989). Triplicate lanes of one gel were each loaded with $30 \mu \mathrm{g}$ protein. After electrophoresis, the gel was cut in three sections and washed three times with $0.1 \mathrm{M}$ sodium phosphate buffer ( $\mathrm{pH} 7)$. Two sections were incubated at $77^{\circ} \mathrm{C}$ in $10 \mathrm{ml}$ of the same buffer containing either X-Gal or 5 -bromo-4-chloro-3-indolyl $\beta$-Dglucopyranoside $\left(0.5 \mathrm{mg} \mathrm{m}^{-1}\right)$ for $10-20 \mathrm{~min}$. A blue band appeared in lanes containing extracts prepared from cells grown in a carbon source that induced the enzyme's synthesis. The third gel section was stained for protein with Coomassie brilliant blue.

cAMP measurements. $T$. neapolitana grown in $1 \mathrm{l}$ defined medium containing $0.5 \%(\mathrm{w} / \mathrm{v})$ glucose, lactose, cellobiose, sucrose, maltose, fructose, xylose, ribose, galactose, starch, yeast extract or a mixture of $0.5 \%(\mathrm{w} / \mathrm{v})$ lactose and $0.05 \%$ $(\mathrm{w} / \mathrm{v})$ glucose was used to prepare cell-free extracts. A $100 \mathrm{ml}$ culture of E. coli grown in M9 medium supplemented with $0.5 \%(\mathrm{w} / \mathrm{v})$ of either lactose or glucose served as positive and negative controls, respectively. A $100 \mu \mathrm{l}$ aliquot of each extract was saved and used for protein determinations. The cAMP concentrations were measured using an enzyme-immunoassay kit (Amersham International) following extraction from cellfree extracts as recommended by the manufacturer. Briefly, proteins were precipitated from the sonicates with $10 \%(\mathrm{w} / \mathrm{v})$ trichloroacetic acid (TCA). Excess TCA was removed from the supernatant by four extractions with 5 vols each of watersaturated diethyl ether followed by lyophilization. The sample was resuspended in assay buffer $(0.05 \mathrm{M}$ acetate buffer, $\mathrm{pH} 5.8$, $0.02 \%, \mathrm{w} / \mathrm{v}, \mathrm{BSA}$ and $0.005 \%, \mathrm{w} / \mathrm{v}$, thimerosal) prior to cAMP measurements. As an internal control, $4.5 \mathrm{pmol}$ or $100 \mathrm{fmol}$ cAMP was added to one cell-free extract prior to the TCA precipitation step to evaluate the efficiency of cAMP recovery (typically $61 \%$ ).

Growth rates and carbohydrate utilization. A $10 \mathrm{ml}$ culture of $T$. neapolitana grown in TB medium containing $1 \mathrm{mM}$ glucose was used to inoculate replicates of $100 \mathrm{ml}$ TB medium lacking resazurin and supplemented with either $300 \mu \mathrm{M}$ glucose, $1 \mathrm{mM}$ lactose, $300 \mu \mathrm{M}$ glucose and $1 \mathrm{mM}$ lactose or no carbohydrate. The cultures were incubated at $77^{\circ} \mathrm{C}$ and $1 \mathrm{ml}$ was removed periodically using strict anaerobic technique. The growth rate was monitored by recording the $\mathrm{OD}_{600}$ with a Spectronic $20 \mathrm{D}$ spectrophotometer. The samples were then centrifuged for $10 \mathrm{~min}$ at $12000 \mathrm{~g}$ and the supernatants were stored at $-20^{\circ} \mathrm{C}$ until carbohydrate determinations were made. 
The glucose concentrations in the samples were measured enzymically using the coupled hexokinase/glucose-6-phosphate dehydrogenase assay described by Chaplin (1986) modified as follows. The assay buffer contained $0.05 \mathrm{M}$ triethylamine buffer (pH 7.5), $4 \mathrm{mM} \mathrm{MgCl}_{2}, 726 \mu \mathrm{M}$ ATP, $523 \mu \mathrm{M}$ NADP, $28 \mathrm{U}$ hexokinase $\mathrm{ml}^{-1}$ and $14 \mathrm{U}$ glucose-6-phosphate dehydrogenase $\mathrm{ml}^{-1}$. The reaction was started by mixing $0.1 \mathrm{ml}$ sample with $1 \mathrm{ml}$ assay buffer pre-warmed to the assay temperature of $37^{\circ} \mathrm{C}$ followed by incubation for $30 \mathrm{~min}$. The amount of NADPH produced (directly proportional to the glucose concentration) was monitored at $340 \mathrm{~nm}$. The glucose concentration was calculated using a standard curve, linear at glucose concentrations ranging from $44 \mu \mathrm{M}$ to $1 \mathrm{mM}$. The lactose content was determined after addition of $14 \mathrm{U} \beta$-galactosidase to the samples and incubation for another $1.5 \mathrm{~h}$ at $37^{\circ} \mathrm{C}$.

\section{RESULTS}

\section{$\beta$-Galactosidase and $\beta$-glucosidase activities in cell extracts}

The enzyme activities for $\beta$-galactosidase and $\beta$-glucosidase in $T$. neapolitana grown in defined media are summarized in Table 1. Lactose, galactose and cellobiose induced $\beta$-galactosidase specific activities of $1 \cdot 19,1 \cdot 78$ and $1.34 \mathrm{U}$ (mg protein $)^{-1}$, respectively. In contrast, cells grown on glucose, maltose, fructose, sucrose, xylose, ribose or starch had no detectable $\beta$-galactosidase activity. Gabelsberger et al. (1993) have cloned and expressed the $\beta$-glucosidase gene from Thermotoga maritima in E. coli and found it also has $\beta$-galactosidase activity. We therefore measured the $\beta$-glucosidase activity in these extracts. Cellobiose was the only carbon source tested that induced $\beta$-glucosidase activity, yielding a specific activity of $1.63 \mathrm{U}$ (mg protein $)^{-1}$. Thus, T. neapolitana possesses either one $\beta$-galactosidase and a bifunctional carbohydrase or a $\beta$ glucosidase and one or more $\beta$-galactosidases that are differentially regulated. (a)

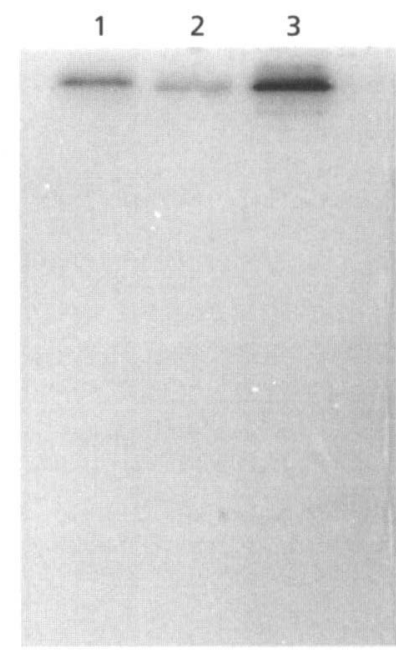

(b)

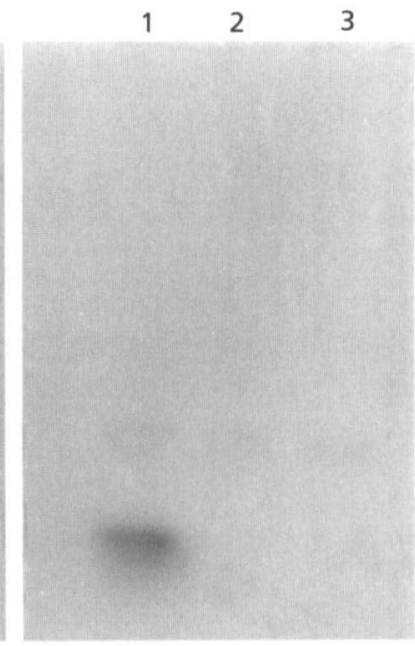

Fig. 1. Enzyme activity patterns of cell-free extracts resolved on a native polyacrylamide gel. The duplicate samples were loaded on the gel and stained with either X-Gal (a) or 5-bromo-4chloro-3-indolyl $\beta$-D-glucopyranoside (b). The extracts were prepared from cells grown in defined medium supplemented with: cellobiose, lane 1; glucose, lane 2 ; lactose, lane 3 . This image was digitally processed using Adobe Photoshop version 2.1.

\section{Electrophoretic resolution of enzyme activity}

To differentiate between these possibilities, the activities were resolved by native PAGE. The cell-free extracts of $T$. neapolitana grown in defined cellobiose, glucose or lactose media were separated on native polyacrylamide gels and stained for $\beta$-galactosidase or $\beta$-glucosidase activity. The results are shown in Fig. 1. The $\beta$ -

\section{Table 1. Induction of $\beta$-galactosidase and $\beta$-glucosidase in $T$. neapolitana}

Cells were grown in defined media containing $0.5 \%$ carbohydrate, except in experiments using two carbon sources (lactose, galactose or cellobiose and glucose), where the glucose concentration was $0.05 \%$. Cells were grown for $17 \mathrm{~h}$, except with lactose and galactose, which were incubated for $36 \mathrm{~h}$. The values are means of three determinations (each performed in duplicate) \pm the standard error of the means.

\begin{tabular}{|lcc|}
\hline Carbon source & \multicolumn{1}{c|}{ Specific activities [U (mg protein) ${ }^{\mathbf{1}}$ ] } \\
\cline { 2 - 3 } & $\boldsymbol{\beta}$-Galactosidase & $\boldsymbol{\beta}$-Glucosidase \\
\hline Lactose & $1.19 \pm 0.33$ & $<0.05$ \\
Galactose & $1 \cdot 78 \pm 0.05$ & $<0.05$ \\
Cellobiose & $1.34 \pm 0.26$ & $1.63 \pm 0.09$ \\
Glucose, fructose, xylose, & $<0.05$ & $<0.05$ \\
ribose, maltose, sucrose & & \\
and starch & $<0.05$ & $<0.05$ \\
Lactose and glucose & $<0.05$ & $<0.05$ \\
Galactose and glucose & $1.02 \pm 0.16$ & $1.57 \pm 0.2$ \\
Cellobiose and glucose & & \\
\hline
\end{tabular}



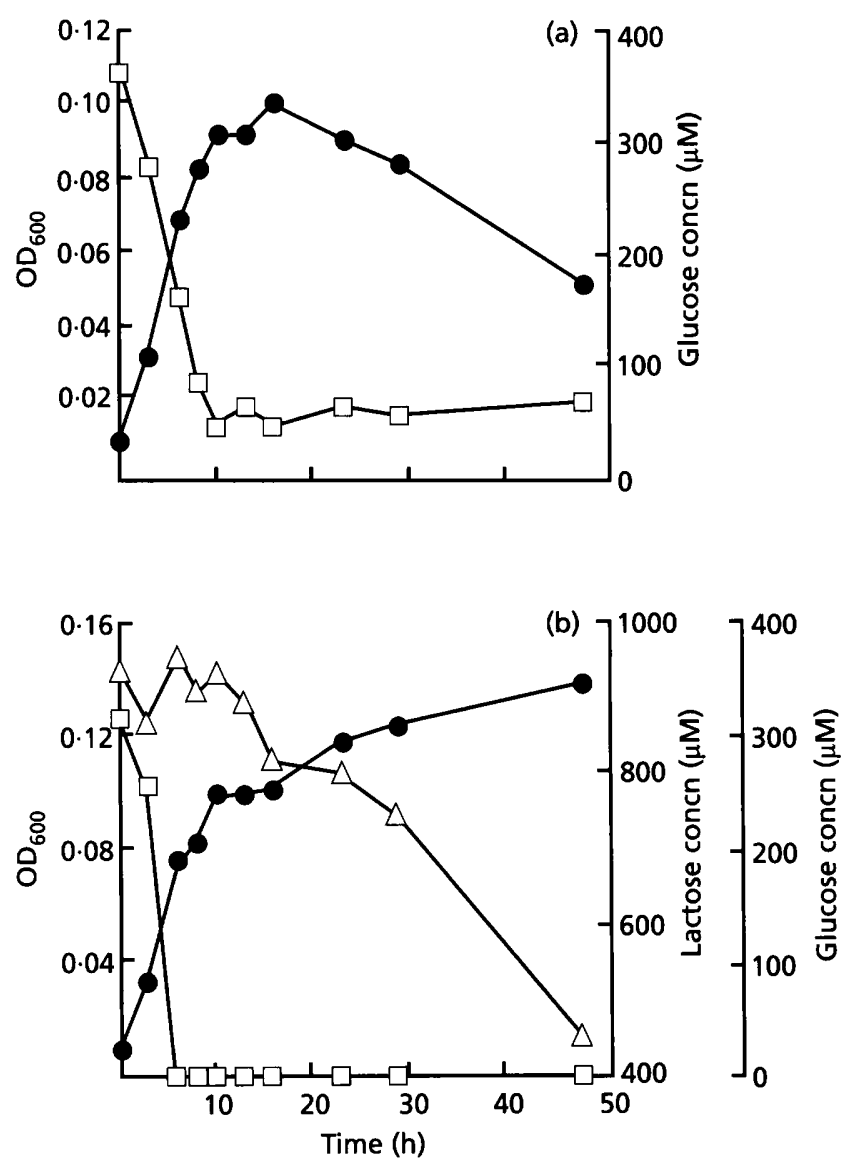

Fig. 2. Growth of $T$. neapolitana NS-E on TB medium supplemented with (a) glucose or (b) glucose and lactose. The inocula were pre-grown on $1 \mathrm{mM}$ glucose. Optical density; $\square$, glucose concentration; $\triangle$, lactose concentration. Each datum represents the mean of measurements from at least two culture values.

galactosidase activity was high in lactose- (Fig. 1a, lane 3) and cellobiose-grown cells (Fig. 1a, lane 1). The glucosegrown cells (lane 2 ) showed weak $\beta$-galactosidase activity, suggesting that X-Gal is a more sensitive indicator of activity than ONPG, used in the experiments for Table 1. In addition, only cellobiose-grown cells contained $\beta$ glucosidase activity (Fig. 1b, lane 1), consistent with the data in Table 1. The enzyme activities corresponding to $\beta$-galactosidase and $\beta$-glucosidase localized to different areas of the gel. These results exclude the possibility that a bifunctional carbohydrase accounts for both activities in cellobiose-grown cells.

\section{Catabolite repression of $\boldsymbol{\beta}$-galactosidase activity}

We further explored the regulation of these enzymic activities by growing cells in the presence of two carbon sources (Table 1). Cells were grown in defined medium containing $0.5 \%(\mathrm{w} / \mathrm{v})$ lactose and $0.05 \%(\mathrm{w} / \mathrm{v})$ glucose, $0.5 \%(\mathrm{w} / \mathrm{v})$ galactose and $0.05 \%(\mathrm{w} / \mathrm{v})$ glucose or $0.5 \%$ $(\mathrm{w} / \mathrm{v})$ cellobiose and $0.05 \%(\mathrm{w} / \mathrm{v})$ glucose. $\beta$-Galacto- sidase activity was not detected in extracts of cells grown on lactose or galactose with glucose. However, extracts of cells grown on cellobiose and glucose possessed $86 \%$ of the $\beta$-galactosidase and $96 \%$ of the $\beta$-glucosidase activity found in extracts of cells grown on cellobiose alone. Therefore, $\beta$-galactosidase activity is subject to catabolite repression only when induced by lactose or galactose.

Cells grown with lactose in combination with other sugars showed varying levels of $\beta$-galactosidase activity. Growth with both $0.5 \%(\mathrm{w} / \mathrm{v})$ lactose and $0.5 \%(\mathrm{w} / \mathrm{v})$ sucrose allowed full expression of $\beta$-galactosidase activity $\left[1 \cdot 1 \mathrm{U}(\mathrm{mg} \text { protein })^{-1}\right]$. Preliminary studies have shown that xylose, maltose and fructose decrease $\beta$-galactosidase activities in cells grown with these sugars and lactose (data not shown). When presented as sole carbon sources, growth rates were highest with starch, maltose, glucose, cellobiose, fructose and sucrose, lower with xylose and ribose and lower still with lactose and galactose.

Fig. 2(b) shows a typical growth curve for T. neapolitana in a complex medium containing $300 \mu \mathrm{M}$ glucose and $1 \mathrm{mM}$ lactose (in this experiment the inoculum was grown on $1 \mathrm{mM}$ glucose). There was an immediate increase in the number of cells during the first $10 \mathrm{~h}$ of incubation, coinciding with a sharp decrease in the glucose concentration in the medium. This growth rate was nearly identical to the rate of growth in medium containing glucose alone (Fig. 2a). After the glucose in the medium was consumed, the cells stopped growing for $6 \mathrm{~h}$. This lag period was followed by a second growth phase at the same time the lactose was consumed (Fig. 2b).

We measured the $\beta$-galactosidase activity in cells harvested after 8 and $48 \mathrm{~h}$ of incubation. Cells grown on $300 \mu \mathrm{M}$ glucose or $300 \mu \mathrm{M}$ glucose and $1 \mathrm{mM}$ lactose for $8 \mathrm{~h}$ had no detectable $\beta$-galactosidase activity. However, at $48 \mathrm{~h}$, we measured $0.76 \mathrm{U}$ (mg protein $)^{-1} \beta$-galactosidase activity in cells growing on $300 \mu \mathrm{M}$ glucose and $1 \mathrm{mM}$ lactose, which corresponds to the second (lactose) growth phase. This induction pattern of $\beta$-galactosidase activity, diauxic growth on lactose and glucose and the mixed carbohydrate substrate experiments show that $T$. neapolitana is able to prioritize carbon sources, exhibiting catabolite repression.

\section{CAMP measurements}

We measured the cAMP concentration within cells to determine if it plays a role in catabolite repression. The levels of cAMP were measured in cells grown in defined media supplemented with $0.5 \%(\mathrm{w} / \mathrm{v})$ different carbon sources. E. coli $\mathrm{K} 12$ cells grown in minimal lactose and glucose media served as positive and negative controls, respectively. A $61 \%$ extraction efficiency was determined using a $T$. neapolitana extract with cAMP added ( $4.5 \mathrm{pmol})$. The cAMP levels in T. neapolitana did not vary significantly irrespective of the carbon source. The values obtained were [in fmol ( $\mathrm{mg}$ protein $)^{-1}$, corrected for extraction efficiency]: lactose, 54; galactose, 90; cellobiose, 66; glucose, 44; lactose and glucose, 126; cellobiose and glucose, 280 ; maltose, 114 ; fructose, 81 ; 
sucrose, 99 ; xylose, 76 ; ribose, 80 ; starch, 61 ; yeast extract, 138; yeast extract and glucose, 165. The low cAMP values were not due to phosphodiesterase activity in extracts during cell manipulations since no phosphodiesterase activity was detectable in extracts at room temperature or at $4{ }^{\circ} \mathrm{C}$ (data not shown). In contrast, $E$. coli grown on lactose contained 5.1 pmol cAMP (mg protein $)^{-1}$ while glucose-grown cells contained only $166 \mathrm{fmol}$ (mg protein $)^{-1}$. Thus, cAMP apparently does not play a role in the regulation of $\beta$-galactosidase activity in T. neapolitana.

\section{DISCUSSION}

Our results demonstrate that $T$. neapolitana is able to prioritize the use of carbon sources, exhibiting diauxic growth on medium containing limiting amounts of glucose and excess lactose. Furthermore, $\beta$-galactosidase activity is regulated and does not appear to involve cAMP. In addition, preliminary experiments show that $T$. neapolitana, unlike T. maritima (Gabelsberger et al., 1993), does not possess a bifunctional $\beta$-glucosidase enzyme containing $\beta$-galactosidase activity.

E. coli and Gram-positive organisms differ in how $\beta$ galactosidase synthesis is regulated. In E. coli and related organisms, a positive regulation exists that is mediated by high levels of cAMP produced in the absence of glucose (Beckwith, 1987). cAMP is part of a global regulatory network that increases expression of a number of operons, including the lactose operon (Magasanik \& Neidhardt, 1987). In addition to these regulatory mechanisms, the presence of glucose prevents lactose uptake, called inducer exclusion (Postma et al., 1993). Gram-positive bacteria lack the positive regulatory aspect of $E$. coli $\beta$ galactosidase regulation, i.e. cAMP does not play a role (Chambliss, 1993). Glucose repression is attributed to inducer exclusion and/or inducer expulsion, where lactose is ejected from the cells. In both cases the inducer is prevented from interacting with the bound repressor thereby preventing expression of the lactose operon.

Although T. neapolitana is a Gram-negative bacterium, $\beta$ galactosidase regulation appears to be more similar to that of Gram-positive bacteria. This type of regulation may also be present in E. coli since an uncharacterized cAMPindependent mechanism has been observed (Magasanik \& Neidhardt, 1987). Failure of glucose to inhibit cellobioseinduced $\beta$-galactosidase suggests that $T$. neapolitana may rely on inducer exclusion and/or expulsion to mediate catabolite repression. Therefore, in the presence of glucose, lactose and/or galactose, but not cellobiose, may be prevented from entering cells and/or ejected from the cells. We are currently investigating whether these physiological processes take place in T. neapolitana.

Our data do not rule out the possibility of there being two $\beta$-galactosidases in T. neapolitana. If there are two, they are indistinguishable by native PAGE. Further, each is differentially regulated by lactose and cellobiose, but both are cAMP-independent. Two $\beta$-glucosidase activities were found in the Thermotoga sp. strain FjSS3-B.1 (Ruttersmith
$\&$ Daniel, 1993). One was purified and $\operatorname{did}$ not have $\beta$ galactosidase activity and the second was not characterized. In T. maritima, $\beta$-galactosidase activity is found in both a LacZ-like $\beta$-galactosidase and a broad-specificity $\beta$ glucosidase (Gabelsberger et al., 1993). We have not observed the latter activity in T. neapolitana. Recently, Bok et al. (1995) reported the purification of two $\beta$-glucosidases induced by cellobiose in $T$. neapolitana. However, they do not report whether they have $\beta$-galactosidase activity. To determine the number of $\beta$-galactosidase activities present in $T$. neapolitana, further characterization of the two inducible activities will be necessary.

The genus Thermotoga belongs to one of the deepest phylogenetic branches within the Bacteria and represents the earliest lineage of bacterial heterotrophs. Therefore, it is a good subject for comparative analyses that can be used to increase our understanding of how regulatory mechanisms evolved. Since the mechanism of induction for lactose utilization in T. neapolitana and Gram-positive bacteria is cAMP-independent, the involvement of cAMP in the induction of $\beta$-galactosidase synthesis may be a more recent development in the evolution of catabolic regulation.

\section{ACKNOWLEDGEMENTS}

We are grateful to Gregory Cook and Michael Galperin for helpful discussions. This work was supported by grants from the National Science Foundation (DCB-9105403), the Department of Energy (DE-FG02-93ER20122), the Office of Naval Research (N00014-91-J-1358), and the University of Connecticut Research Foundation.

\section{REFERENCES}

Beckwith, J. (1987). The lactose operon. In Escherichia coli and Salmonella typhimurium: Cellular and Molecular Biology, pp. 1444-1452. Edited by F. C. Neidhardt, J. L. Ingraham, K. Brooks Low, B. Magasanik, M. Schaechter \& H. E. Umbarger. Washington, DC: American Society for Microbiology.

Belkin, S., Wirsen, C. O. \& Jannasch, H. W. (1986). A new sulfurreducing, extremely thermophilic eubacterium from a submarine thermal vent. Appl Environ Microbiol 51, 1180-1185.

Bok, J. D., Swiatek, G. C. \& Eveleigh, D. E. (1995). $\beta$-Glucosidases of Thermotoga neapolitana: kinetic studies, end-product resistance and transglycosylation. Abstract presented at the 95th General Meeting of the American Society for Microbiology, 21-25 May 1995. Washington, DC: American Society for Microbiology.

Botsford, J. L. \& Harman, J. G. (1992). Cyclic AMP in prokaryotes. Microbiol Rev 56, 100-122.

Bradford, M. M. (1976). A rapid and sensitive method for the quantitation of microgram quantities of protein utilizing the principle of protein-dye binding. Anal Biochem 72, 248-254.

Chambliss, G. H. (1993). Carbon source-mediated catabolite repression. In Bacillus subtilis and Other Gram-Positive Bacteria: Biochemistry, Pbysiology, and Molecular Genetics, pp. 213-219. Edited by A. L. Sonenshein, J. A. Hoch \& R. Losick. Washington, DC: American Society for Microbiology.

Chaplin, M. F. (1986). Monosaccharides. In Carbobydrate Analysis: a Practical Approach, pp. 1-36. Edited by M. F. Chaplin \& J. F. Kennedy. Oxford: IRL Press. 
Childers, S. E., Vargas, M. \& Noll, K. M. (1992). Improved methods for the cultivation of the extremely thermophilic bacterium Thermotoga neapolitana. Appl Environ Microbiol 58, 3694-3699.

Gabelsberger, J., Liebl, W. \& Schleifer, K.-H. (1993). Cloning and characterization of $\beta$-galactoside and $\beta$-glucoside hydrolysing enzymes of Thermotoga maritima. FEMS Microbiol Lett 109, 131-138.

Jannasch, H. W., Huber, R., Belkin, S. \& Stetter, K. (1988). Thermotoga neapolitana sp. nov. of the extremely thermophilic, eubacterial genus Thermotoga. Arch Microbiol 150, 103-104.

Magasanik, B. \& Neidhardt, F. C. (1987). Regulation of carbon and nitrogen utilization. In Escherichia coli and Salmonella typhimurium: Cellular and Molecular Biology, pp. 1318-1325. Edited by F. C. Neidhardt, J. L. Ingraham, K. Brooks Low, B. Magasanik, M. Schaechter \& H. E. Umbarger. Washington, DC: American Society for Microbiology.

Monod, J. (1947). The phenomenon of enzymatic adaptation. Growth 11, 223-289.
Postma, P. W., Lengeler, J. W. \& Jacobson, G. R. (1993). Phosphoenolpyruvate:carbohydrate phosphotransferase systems of bacteria. Microbiol Rev 57, 543-594.

Ruttersmith, L. \& Daniel, R. M. (1993). Thermostable $\beta$-glucosidase and $\beta$-xylosidase from Thermotoga sp. strain FjSS3-B.1. Biochim Biophys Acta 1156, 167-172.

Sambrook, J., Fritsch, E. F. \& Maniatis, T. (1989). Molecular Cloning: a Laboratory Manual. Cold Spring Harbor, NY : Cold Spring Harbor Laboratory.

Windberger, E., Huber, R., Trincone, A., Fricke, H. \& Stetter, K. (1989). Thermotoga thermarum sp. nov. and Thermotoga neapolitana occurring in African continental solfataric springs. Arch Microbiol 151, 506-512.

Woese, C. R. (1987). Bacterial evolution. Microbiol Rev 51, 221-271.

Received 19 June 1995; accepted 19 September 1995. 